\title{
No association between islet cell antibodies and coxsackie $B$, mumps, rubella and cytomegalovirus antibodies in non-diabetic individuals aged 7-19 years
}

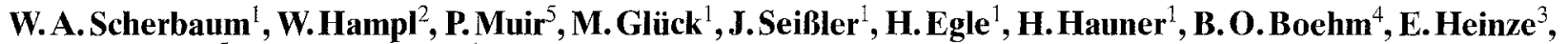 \\ J.E.Banatvala ${ }^{5}$ and E.F.Pfeiffer \\ Departments of ${ }^{1}$ Internal Medicine I, ${ }^{2}$ Virology, and ${ }^{3}$ Paediatrics, University of Ulm, ${ }^{4}$ Department of Endocrinology and Metabolism, \\ University Hospital Frankfurt, FRG, and ${ }^{5}$ Department of Virology, United Medical and Dental Schools of Guy's and St. Thomas' \\ Hospitals (St. Thomas' Campus), London, UK
}

Summary. Viral antibodies were tested in a cohort of 44 isletcell antibody-positive individuals age 7-19 years, and 44 of their islet cell antibody-negative age and sex-matched classmates selected from a population study of 4208 pupils who had been screened for islet cell antibodies. Anti-coxsackie B1-5 IgM responses were detected in 14 of $44(32 \%)$ of the islet cell antibody-positive subjects and in 7 of $44(16 \%)$ control subjects. This difference did not reach the level of statistical significance. None of the islet cell antibody-positive subjects had specific IgM antibodies to mumps, rubella, or cytomegalovirus. There was also no increase in the pre- valence or the mean titres of anti-mumps-IgG or $\operatorname{IgA}$ and anti-cytomegalovirus-IgG in islet cell antibody-positive subjects compared to control subjects. These results do not suggest any association between islet cell antibodies, and possibly insulitis, with recent mumps, rubella or cytomegalovirus infection. Further studies are required to clarify the relationship between islet cell antibodies and coxsackie $B$ virus infections.

Key words: Viral antibodies, Beta-cell function, population study.
There is considerable evidence implicating virus infection in the pathogenesis of Type 1 (insulin-dependent) diabetes mellitus, particularly infection with coxsackie B and other enteroviruses, but also mumps, rubella and cytomegalovirus. This evidence is based on studies in animal models [1], anecdotal case reports in which viruses have been isolated from patients at the time of Type 1 diabetes onset [2-4] and seroepidemiological studies to determine the prevalence of virus-specific IgM responses in patients with recently diagnosed Type 1 diabetes [5-9], indicating that virus infection is present in a proportion of patients around the time of diabetes onset. In view of the long incubation period before clinical diabetes becomes apparent in man, it is pertinent to consider whether virus infection may be involved in the initiation of the disease process, rather than simply the precipitation of disease in patients with already compromised Beta-cell function. To this end we have sought evidence of virus infection in healthy schoolchildren with islet cell antibodies (ICA), a prediabetic serological marker [10-14]. This study forms part of a wider study to assess additional makers of the prediabetic state, and their relationship to the presence of ICA [15].

\section{Subjects and methods}

\section{Study population}

Between July 1988 and July 1989, 4208 students (age range 7-21 years; mean age 13.9 years) from 19 schools in Ulm/Alb-Donau County, FRG, were investigated. The aim of this study was to screen for markers which maybe associated with Type 1 diabetes, and to define the frequency of certain viral antibodies associated with the presence of ICA. The study was performed in accordance with the principles of the Declaration of Helsinki. Sera were stored at $-20^{\circ} \mathrm{C}$ until they were used for further testing.

Of the 4208 pupils tested $44(1.05 \%)$ were positive for ICA. These ICA-positive individuals were selected for antiviral antibody determination. The median age of ICA-positive subjects was 13.5 years (range $7-19$ years). Six of the $44(13.6 \%)$ were positive for complement-fixing ICA.

\section{Control subjects}

For each ICA-positive individual, an age and sex-matched classmate was selected, the serum sample being collected on the same day as that of the proband. 
Table 1. Anti-viral antibodies in islet cell antibody-positive and in islet cell antibody-negative non-diabetic probands

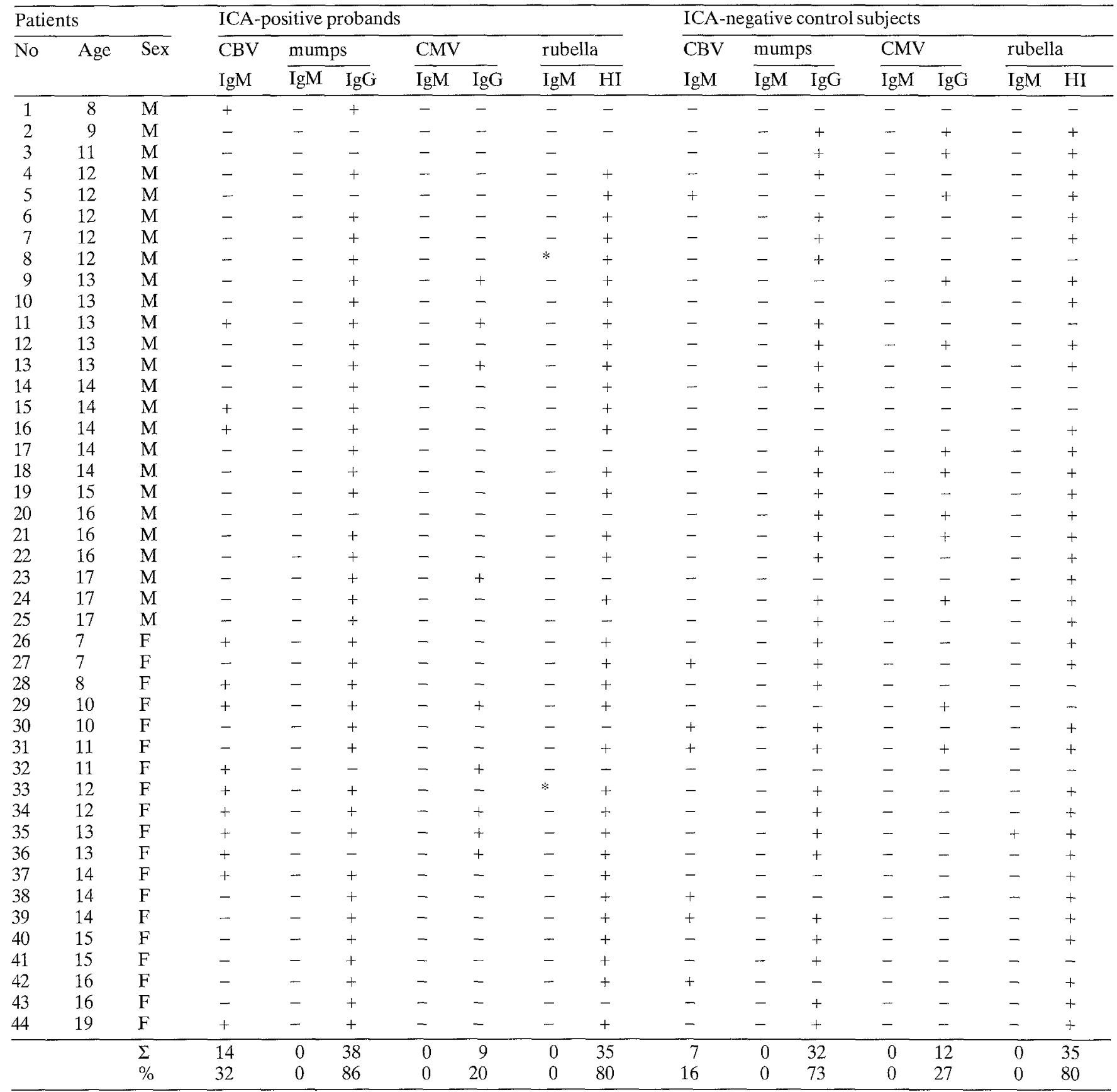

CBV, coxsackie B1-5 virus; CMV, cytomegalovirus; HI, haemagglutination inhibition test; + , positive test result; - , negative test result; *, not tested

\section{Screening for islet cell antibodies (ICA)}

Sere were tested by the standard indirect immunofluorescence test using $4 \mu \mathrm{m}$ cryostat sections of human blood group 0 pancreas as previously described [16]. Positive sera were then tested until endpoint dilutions. In an international quality control assessment at primary screening our laboratory achieved values of $100 \%$ for consistency, sensitivity, specificity, and validity (Second Juvenile Diabetes Workshop ICA Proficiency Program; Lab ID NO.116, WAS). ICA test results were transferred to Juvenile Diabetes Foundation (JDF) units using the standard curve provided for the workshop [17]. The lower limit of detection in our assay up to now is $5 \mathrm{JDF}$ units with a laboratory specificity and consistency of $100 \%$ (Fifth IDW ICAProficiency Program). A positive ICA result was defined by repli- cate titres of 10 JDF units or greater. The tests were carried out in a blinded manner by two investigators (G.T. and G.G.).

ICA-positive sera were further tested for complement fixingICA using an indirect immunofluorescent method as described [16].

\section{Virus-specific antibody responses}

Coxsackie B virus specific IgM responses were detected by an M-antibody capture ELISA technique employing monovalent reagents to coxsackie B1-5 viruses as previously described [5]. Antibodies to rubella virus were detected by a haemagglutination inhibition test (HI) using heparin- $\mathrm{MnCl} 2$ and chick erythrocytes as de- 
scribed in detail elsewhere [18]. To confirm rubella HI results, a commercial single radial haemolysis (SRH) test was performed (Dr. W. Koch/Dr. C. Merk, Ochsenhausen, FRG). Rubella IgM antibodies were measured by a commercial ELISA (Rubazyme-M-Test, Abbot, Wiesbaden, FRG).

IgM antibodies to cytomegalovirus were detected by the cytomegalovirus-IgG-ELA (Medac, Hamburg, FRG), and cytomegalovirus- $\operatorname{IgA}$ antibodies, by a commercial indirect immunofluorescence test (Viramed, Martinsried, FRG). Only cytomegalovirus-IgG positive sera were tested for cytomegalovirus-IgA. Anti-Mumps antibodies of the IgG-and IgM type were tested by separate commercial ELISA's (Enzygnost-Parotitis, Behringwerke, Marburg, FRG). Anti-mumps IgM positive sera were tested by a second ELISA (mumps-IgM-ELA, Medac, Hamburg, FRG). Anti-mumps IgA antibodies were detected by indirect immunofluorescence test (Viramed, Martinsried, FRG). Only sera positive for anti-mumps IgG were tested for anti-mumps IgA.

The above-mentioned tests were all conducted and interpreted according to the manufacturer's instructions.

\section{Statistical analysis}

Fisher's exact test (two-tail) was applied to compare the antibody frequences of ICA-positive and ICA-negative control subjects.

\section{Results}

Most of the overall data on anti-viral antibodies in the 44 non-diabetic ICA-positive individuals and their ICAnegative matched control subjects are given in Table 1. Of 35 ICA-positive individuals who answered a specific questionaire, 25 had been vaccinated for mumps and rubella virus 3 to 12 years prior to ICA testing.

The difference between coxsackie B1-5 specific IgM responses in the ICA-positive and ICA-negative control subjects was not statistically significant. No increase of anti-coxsackie B1-5 IgM responses could be found in the six individuals with CF-ICA; only two of the six were positive for anti-coxsackie B1-5 IgM. The median age of the coxsackie B1-5 IgM-positive individuals was 12.1 years (range: 7-19 years) in the ICA-positive probands, and 12.0 years (range: $7-16$ years) in the control subjects.

There were no increases in anti-mumps-IgM, antimumps-IgA, anti-cytomegalovirus-IgA, anti-cytomegalovirus-IgG or anti-rubella antibodies in ICA-positive as compared to control subjects.

\section{Discussion}

Islet cell antibodies indicating an autoimmune reaction to islet cells, are known to precede the onset of Type 1 diabetes by months or even years [10-14]. Assuming that viruses may play a role in the direct initiation of autoimmune insulitis, the association of recent virus infections with the appearance of ICA in the pre-diabetic period rather than at the onset of disease should be noted. Precise matching of patients and control subjects by area of residence is often difficult to achieve, particularly when the group studied consists of hospital in-patients [5]. The requirements for appropriate control subjects are ideally met in our study where age- and sex-matched class-mates of the probands were used.

This study provided no evidence of an association between the presence of ICA and recent mumps, postnatally acquired rubella or cytomegalovirus infection. In previous studies no association between these virus infections and the onset of Type 1 diabetes was found [5-7]. Although mumps infection may result in transient ICA, islet cell surface antibodies and insulin-autoantibody responses [19-20], and may occasionally cause Type 1 diabetes [21], there is little evidence that these viruses are a significant cause of Type 1 diabetes.

The results of a low prevalence of IgM antibodies to the rubella and mumps viruses are not unexpected since $\operatorname{IgM}$ antibodies to these non-persistent viruses appear almost exclusively at primary infection. This is important in light of the fact that the prevalence of mumps or rubella immunity at age 13 was $76 \%$ before the vaccination era, and $71 \%$ of our pupils who responded to a questionaire had been vaccinated previously. The low prevalence of recent infections in our cohort is also supported by the methodologically-unrelated measurement of $\operatorname{IgA}$ antibodies to mumps and cytomegalovirus.

Results of coxsackie B virus-specific IgM studies were less clear. Although the difference in prevalence between ICA positive and negative individuals was not statistically significant, a study of larger numbers would be required to exclude such an association. A number of serological studies have found a higher prevalence of coxsackie $B$ virus-specific $\operatorname{IgM}$ responses in patients at Type 1 diabetes onset compared with control subjects $[5,8,9,22]$ while others have not [6-7]. In one study, the prevalence of IgM among Type 1 diabetic patients showed considerable geographic and temporal variation, ranging from $0-76 \%$ [9]. This probably reflects fluctuations in the prevalence of pancreotropic and diabetogenic strains of coxsackie $B$ viruses. A clearer understanding of the role of coxsackie $B$ and other enteroviruses in the pathogenesis of Type 1 diabetes is likely to require longitudinal study of ICA-positive subjects and other susceptible individuals, such as first-degree relatives of Type 1 diabetic patients. This would allow evidence of virus infections to be studied in relation to the appearance, rather than the presence of ICA and other pre-diabetic markers.

Acknowledgements. We thank Ms. G.Trischler, Ms. G. Graf and Ms. M. Just for their technical help with the antibody assays and Ms. S.Simon for typing the manuscript. We also thank Professor L. T. Mertens, Ulm, for helpful discussions. This work was supported by the Deutsche Forschungsgemeinschaft (Sche 225/3-2, Schwerpunkt „Ursachen und Folgen des Diabetes Mellitus“ und Scho 109/ 16-2), the Ministry for Science Baden-Württemberg (LFSP Nr.31 to W.A.S., and the Deutsche Diabetes-Stiftung (to J.S. and B.O.B.), Work carried out at St. Thomas' Hospital was funded by the British Diabetic Association and grant no.14501/1,5 from the Wellcome Trust.

\section{References}

1. Toniolo A, Federico G, Basolo F, Onodera T (1988) Diabetes mellitus. In: Bendinelli M, Friedman E (eds) Coxsackieviruses: a general update. Plenum Press, New York, pp 351-382 
2. Yoon J-W, Austin M, Onodera T, Notkins AL (1979) Virus-induced diabetes mellitus: isolation of a virus from the pancreas of a child with diabetic ketoacidosis. N Engl J Med 300: 1173-1179

3. Gladisch R, Hofmann W, Waltherr R (1976) Myokarditis und Insulitis nach Coxsackie-Virus-Infekt. Z Kardiol 65: 837-849

4. Champsaur H, Dussaix E, Samolyk F, Fabre M, Bach C, Assan R (1980) Diabetes and Coxsackie virus B5 infection. Lancet I: 251

5. Banatvala JE, Bryant H, Scherthaner G et al. (1985) Coxsackie $\mathrm{B}$, mumps, rubella, and cytomegalovirus specific IgM responses in patients with juvenile-onset insulin-dependent diabetes mellitus in Britain, Austria, and Australia. Lancet I: 1409-1412

6. Karjalainen J, Knip M, Hyöty $\mathrm{H}$ et al. (1988) Relationship between serum insulin autoantibodies, islet cell antibodies and Coxsackie-B4 and mumps virus-specific antibodies at the clinical manifestation of Type 1 (insulin-dependent) diabetes. Diabetologia 31: 146-152

7. Tuvemo T, Dahlquist G, Frisk G et al. (1989) The Swedish childhood diabetes study III: IgM against coxsackie B viruses in newly diagnosed Type 1 (insulin-dependent) diabetic children - no evidence of increased antibody frequency. Diabetologia 32: 745-747

8. Frisk G, Folman J, Kobbah M et al. (1985) High frequency of Coxsackie-B-virus-specific IgM in children developing type I diabetes during a period of high diabetes morbidity. J Med Virol 17:219-227

9. Tuvemo T, Frisk G, Friman G, Ludvigsson J, Diderholm H (1988) IgM against Coxsackie B viruses in children developing type I diabetes mellitus - a seven year retrospective study. Diabetes Res 9: 125-129

10. Tarn A, Thomas JM, Dean BM, Schwarz G, Bottazzo GF, Gale EAM (1988) Predicting insulin-dependent diabetes. Lancet I: $845-850$

11. Srikanta S, Ganda OMP, Rabizadeh A, Soeldner JS, Eisenbarth GS (1985) First degree relatives of patients with type I diabetes mellitus: islet cell antibodies and abnormal insulin secretion. $\mathrm{N}$ Engl J Med 313: 461-464

12. Riley WJ, MacLaren NK, Krischer J et al. (1990) A prospective study of the development of diabetes in relatives of patients with insulin-dependent diabetes. N Engl J Med 323: 67-72

13. Wagener DK, Sacks JM, LaPorte RE, Macgregor JM (1982) The Pittsburgh study of insulin-dependent diabetes mellitus: risk for diabetes among relatives of IDDM. Diabetes 31:136-44
14. Kuglin G, Bertrams J, Linke C, Gries FA, Kolb H (1989) Prevalence of cytoplasmatic islet cell antibodies and insulin autoantibodies is increased in subjects with genetically defined high risk for insulin-dependent diabetes mellitus. Klin Wochenschr 67: 66-73

15. Seißler J, Speck U, Glück M et al. (1990) Epidemiologische Untersuchung zur Erkennung der präklinischen Phase des Typ I Diabetes bei Schulkindern. Populationsstudie Ulm-Frankfurt. Dtsch Med Wochenschr 115: 689-694

16. Scherbaum WA, Mirakian R, Pujol-Borrell R, Dean BM, Bottazzo GF (1986) Immunochemistry in the study and diagnosis of organ-specific autoimmune diseases. In: Polak JM, Van Noorden $S$ (eds) Immunochemistry. Modern methods and applications. Wright, Bristol pp 456-476

17. Bonifacio E, Lernmark $\AA$, Dawkins RL et al. (1988) Serum exchange and use of dilutions have improved precision of measurement of islet cell antibodies. J Immunol Method 106: 83-88

18. Antoniadis G, Enders G, Lennartz H, Thomssen R (1974) Standardisierte Technik zur Durchführung des Röteln-HA- und HAH-Testes. Bundesgesundheitsblatt 17:329-335

19. Helmke K, Otten A, Willems W (1980) Islet cell antibodies in children with mumps infection. Lancet II: 211-212 (Letter)

20. Ratzmann KP, Strese J, Witt S, Berling H, Keilacker H, Michaelis D (1984) Mumps infections and insulin-dependent diabetes mellitus (IDDM). Diab Care 7: 170-173

21. Rayfield EJ, Seto Y (1978) Viruses and the pathogenesis of diabetes mellitus. Diabetes 27:1126-1142

22. King ML, Bidwell D, Shaikh A, Voller A, Banatvala JE (1983) Coxsackie-B-virus-specific IgM responses in children with insulin-dependent (juvenile-onset; type 1) diabetes mellitus. Lancet I: 1397-1399

Received: 29 May 1991

and in revised form: 28 August 1991

Prof. Dr. W. A. Scherbaum

Department of Internal Medicine

University of Ulm

Robert-Koch-Straße 8

W-7900 Ulm

FRG 